\title{
THE MAXIMUM UTILIZATION OF PASTURE WITH INTENSIVE LIVESTOCK PRODUCTION
}

\author{
Malcolm GuY \\ Farmer, Koputaroa
}

\section{Abstract}

Physical features and stocking capacity of a bcef fattening farm and a family company farm running beef and dairy cattle near Levin are described. Stock and pasture management and the integration of these into a successful all-grass farming enterprise are discussed.

\section{INTRODUCTION}

I am actively involved in farming at Koputaroa, $10 \mathrm{~km}$ north of Levin, on my own beef farm of 135 ha and an adjoining family company farm of 259 ha in tiwo blocks of 1.78 and 121 ha, both dairy and beef.

\section{HOME FARM}

This farm has a capital value of \$196 000 (Government Valuation, October 1975) and rates total $\$ 1250$.

Soil types are Omanuka peaty silt loam, Makerua peaty loam, Kairanga loam (adjoining river) and Pukepuke sand.

The average rainfall is about $1095 \mathrm{~mm}$ and there are annually some 1880 sunshine hours. The land is semi-developed with some stumps remaining but the farm is completely refenced with all electric mains units and internal races. No crops are grown and neither silage nor hay is made.

Five years ago I had a fat lamb and breeding cow stocking policy with a carrying capacity of between 19 and 22 ewe equivalents/ha. Stock are now all cattle, with the csception of 200 ewes.

Stock carried at $30 / 6 / 77$ were:

60 2-vear beef steers

62 2-year beef heifers

50 Angus in-calf cows

155 yearling fattening bulls

60 15-month fattening bulls

312 6-12 month bulls

699 cattle plus 200 sheep 
Stock units calculated for the Incentive Scheme are 3408 $(25.43 / \mathrm{ha})$. A year before and for two seasons prior to that, the stocking rate during June/ July/August was approximately 22 units/ha.

\section{STOCK POLICY}

Most of the cattle are bulls. I try to sell approximately half the cattle as $21 / 2$-year-olds each year, attempting to reach $260 \mathrm{~kg}$ carcass weight to gain a premium price. This enables a flexible buying and selling policy and avoids a situation requiring "panic buying", particularly in October and November when feed is plentiful. I try to buy and sell out of season - i.e., summer, autumn, and winter when there tend to be fewer buyers "on the market".

Because of this policy of carrying stock through two winters, I can be rather restrictive in feeding the older cattle and therefore carry more and gather the compensatory weight gains in the spring/summer.

A replacement cost system is operated with the profit projected - i.e., I sell one $2 \frac{1}{1} 2$-year-old at $\$ 220$, buy a weaner at $\$ 50$, and the difference of $\$ 170$ over 2 years is $\$ 85 /$ heast/year. Similarly, the $\$ 50$ weaner projecting the market up or down will be worth $\$ 200-\$ 240$ in 2 years' time (hopefully). I still run some traditional beef cows for the following reasons:

(1) I can supply a diverse market - i.e., local trade, stores or export.

(2) Steers are more easily grazed out should extra feed be available in the surrounding district.

(3) The weaned cows can be done very hard in early autumn which helps to save feed for winter rationing.

(4) Some years I am able to sell cows as culls around $200 \mathrm{~kg}$ carcass weight and buy in others at $140 \mathrm{~kg}$, gaining $\$ 30 /$ $\$ 40$ on the cow and still having the calf as additional profit.

(5) Breeding some replacements cushions the buying-in costs.

\section{Management POLICY}

I have endeavoured to have a low cost system. There is no machinery, except a 4-wheel-drive vehicle for transport between the three blocks and any hay feeding necessary, Fencing, drain- 
age, and fertilizer application have been done by contract and some family help is used for morning electric fencing during rush periods.

My grazing policy is centred upon an all-grass feeding system. To achieve this:

(1) I try to utilize grass directly with animals to avoid waste and keep costs and volume of work down (taking into account the 1600 cattle involved on both home and company farms).

(2) Build up a "bank of feed" in autumn as soon as the first rains start. This is achieved by reducing the amount of grass fed, and feeding some hay if necessary. Most big animals are sold by then, because the weight gain has slowed and I always try to avoid congestion at the freezing works which seems to happen later in the season.

(3) I try to have a strict grazing rotation, exploiting permanent and temporary electric fencing, using daily breaks for three to four months during the autumn and winter.

(4) I try to have mobs as big as possible-i.e., between 150 and 300 initially - with a six weeks' autumn rotation. I blend together all cattle I can - i.e., 12-month bulls with 21/2year bulls or steers, or 18 -month heifers with the breeding cows. I tend to draft weaners for size and condition (I have two mobs of 164 and 145 this year) because the smaller ones may need additional drenching or more mature feed.

(5) If hay has to be fed because of a flood problem or to slow the rotation, I tend to put the mob concerned on a 1 ha sand pad and feed only hay for 2 to 3 weeks. This seems easier than feeding on, or ahead of a break, and saves pugging.

(6) From early August I begin set-stocking the 18-month cattle at 4 to 5/ha. I keep the smaller weaners on a rotation, and the breeding cows calve behind the electric wire and are continued rotating until about October, usually on the longer feed, in the paddocks with no drains.

(7) Weather usually dictates the size of the breaks given. In frosty conditions I tend to feed less, but during wetter spells, when the grass is growing well, I feed more and move on a faster rotation. Regrowth is better and pugging problems seem less because of this system. 


\section{TOPDRESSING}

Little superphosphate has been used as the land is naturally fertile, and because of an initial low equity, preference was given to expenditure on fencing, drainage, and stock purchases. Sixtyone tonnes superphosphate were applied after the beef boom in 1974 and last season 61 tonnes were applied at $600 \mathrm{~kg} / \mathrm{ha}$ of potassic superphosphate in January-February. This winter I have had more grass and more and better-conditioned stock than ever before, so one could argue the potash has helped. However, we did have a wetter summer-autumn and perhaps my peat country never dried up, consequently growth never stopped.

\section{THE COMPANY FARM}

\section{The DAIRy Unit (138 ha)}

This comprises mainly Levin and Kiwitea silt loam with Ormanuka peaty silt loam. It is well developed with internal metal t-aces and adequate water. A 28 rotary milker was built, costing \$40 000 in 1975 with some Rural Bank finance. Two permanent men are employed and we plan to milk 325 cows this season. In addition, 50 cows were milked through the winter for quota milk. Production last season was $38500 \mathrm{~kg}$ from 270 cows.

\section{Stock Policy}

In the last three years, herd numbers have risen from 180 to 350 cows (we are allowing a culling rate of 25 cows owing to infertility, deaths and mastitis) and this increase has necessitated buying in extra cows during each of the last three years.

All suitable calves are kept for replacements and bull beef. Occasionally, and depending on the need for numbers on the beef unit, extra bull calves are purchased and autumn reared. The two men employed have developed a multiple suckling unit and can feed 60 at a time in different paddocks.

Artificial insemination is practised for two cycles in the spring and then bulls are used to pick up undetected cows. Sometimes we do not get all the calving dates for these later cows, but the essential is having them in calf.

\section{The Beef Unit (121 ha)}

The soils are Makerua peaty loam, Kairanga loam and sandy ridges. This area is used for bull beef production, dairy heifers 
and six to eight weeks off-wintering for the dairy herd. Stock at 30/6/77 was:

$$
\begin{aligned}
& 350 \text { in-calf cows } \\
& 25 \text { empty cows } \\
& 75 \text { 2-year bulls } \\
& 112 \text { 15-month bulls } \\
& 120 \text { yearling bulls } \\
& 5 \text { herd sires } \\
& 40 \text { mixed sex calves }
\end{aligned}
$$

\section{7 head plus 30 sheep}

This is equivalent to 4560 stock units or nearly $18 /$ ha over the total area of 259 ha or $27 /$ ha over the effective dairying acreage.

\section{Company Farm's Grazing Policy}

A long summer and winter rotation with a short spring rotation is practical on the dairy unit. No silage or hay is made and mobs of either bulls or heifers are used to clean up surplus feed in spring. In order to feed the cows adequately prior to calving, mobs of bulls are shut on sand ridges and fed hay for 6 to 8 weeks continuously and the available grass given to the herd. Depending on spring grass growth, some hay is fed to the lactating cows, but we prefer to feed them all grass with a little restriction for a short time after calving.

\section{M anagement Decisions}

These are taken in conjunction with the thoughts and ideas of the directors and the men on the dairy unit. Communication, I believe, is very important and we try to have a free exchange of ideas. I am always conscious of how these men think and endeavour to treat them as I myself like to be treated. Decisions of management are all related to the farm vat and they affect everyone's pocket.

We all have the same thoughts - "Will we have enough feed for most of the year?" - and are all conscious of the need to grow more and waste nothing.

\section{Topdressing}

Nothing less than $500 \mathrm{~kg} / \mathrm{ha}$ of superphosphate has been applied during the past four years on the dairy unit and last season $600 \mathrm{~kg}$ of $30 \%$ potassic superphosphate was used on the back 
of the dairy farm. We budget on $2 \%$ deaths from bloat and have not used potash on these known bloat-prone paddocks. Sometimes copper is injected into the calves and selenium is added to all drenches.

\section{Land Development}

Sixteen hectares have been developed and sown to new grass during the last year. Contractors were used to sow turnips and maize and, after feeding off, pasture mixtures including Ariki, Nui, and Manawa ryegrass with Apanui cocksfoot and Huia white clover were sown after 5 t/ha of lime had been worked into the ground.

After severe droughts (as we had three years ago) or if severe pugging has taken place, we endeavour to oversow using a contractor's disc drill. Success has been only moclerate after droughts.

\section{OBSERVATIONS}

Some gcneral observations on this all-grass system, on my soil types, in the Horowhenua District are:

(1) If care is taken to provide a bank of feed as soon as the first good autumn rains start, good weaners can be wintered without any hay at 7 /ha (and even 10, if not too big), using strict front and back fencing. They will gain a little weight.

(2) Big mobs i.e., 200 weaners and 300 18-month cattle are more easily farmed. Deaths from riding in my 18 -month bulls, however, do have a 'steadying effect on mob size and I budget for $.5 \%$ loss.

(3) Assessment of feed must be done weekly and the amount of dry matter, usually dependent on the spelling time in my view, determines my rotation. I feed the smallest cattle on the wetlest paddocks because they do the least damage.

(4) Electric fences must all work efficiently.

(5) Hay does not seem necessary with grass although in grass stagger situations we use it, of course, The general use of only a little hay 1 have found not applicable - we have even weaned 200 bull calves at 7 weeks old in autumn and fed no hay with no detrimental effects. I have in reserve 3000 bales for flooding or feed shortages, but we have fed during three winters only 5-800 bales.

(6) Drenching regularly seems necessary and we try to drench all younger stock every 3 to 5 weeks, We have occasionally even drenched 2-year cattle, especially in early spring. 
(7) The grazing system is critical in gathering the bank of feed when rains start. I like to think that by the 1 st of May I can budget for sufficient feed until August, when our spring seems to start, although slowly.

(8) No cattle are weighed and I rely on general appearance rather than weight gain, but when selling I tend to kill the tops and bottoms out of each mob first and, on receiving the weights of these, make decisions concerning' the rest. I feed the best available feed to the highest converters, related to price, and when it is gone, or the autumn comes, I kill regardless of weight.

We should all realize weighing cattle requires time and effort and with my policy of sometimes buying "tail-enders", and keeping them to $2 \frac{1}{2}$ years old the following autumn, I do not mind if they are slow converters.

(9) Provided stock are worm-free, we have found that hay can be fed on sand pads with nothing else for 8 weeks. If IS-month bulls receive 1 bale/4 animals their health does not suffer although they visually appear to lose weight.

(10) With strict winter front and back fencing, I am of the opinion that one-third more beef cattle could be farmed through May, June, July and August. These extra stock may not produce as much profit per head, but with few extra costs the total profit is naturally higher. There is no wool to worry about, no milk to produce, and the compensatory growth is there for the taking.

In conclusion I would like to pay tribute to the help we have had, through dairy and beef discussion groups, from Tom Sewell and John Heslop, MAF, Levin, and Don Johnston, Dairy Board Consulting Officer. The practical nature of their help and their experience with pasture and its control have helped towards the all-grass policy we have adopted. Dr R. W. Brougham, through similar visits, has generated much thought and helped us formulate a grass policy emphasizing regrowth, avoiding damage that can occur by overgrazing during the summer, and making use of the advantages of newer species.

I give this paper as one still trying to succeed and in no way suggest that I know the answers. I do know, however, that we have a climate in New Zealand very suitable for pasture. production, and feel that, with all the increasing costs about us, we should utilize to the fullest all we grow. Surely this is one positive way we farmers can all help ourselves. 